\title{
The Role of Traditional Family Motto in the Moral Cultivation of Contemporary Youth*
}

\author{
Yufeng Jiang \\ School of Marxism \\ Zhejiang University \\ Hangzhou, China 310028 \\ Zhejiang Normal University \\ Jinhua, China 321004
}

\begin{abstract}
The family motto contains abundant moral educational thought, its role in contemporary moral cultivation for the youth is mainly reflected as: the motto of patriotic virtues cultivates the youth to love their country, the motto of the spirit of aspiration cultivates the youth to set up their goals, the motto of the virtues of learning cultivates them to be hardworking, and the motto of the virtues of good faith cultivates them to be honest.
\end{abstract}

Keywords-traditional family motto; contemporary; moral cultivation; effect

\section{INTRODUCTION}

Moral quality is the key factor for young adults and talents, which plays an important role in the healthy development of young people. The Chinese nation is a nation that values family and family education. As the crystallization of the ancient family education, family mottoes are a combination of the bottom line standard, vivid morals and the concrete morality. They express the positive energy to educate them with what they should do; or they eradicate the negative effects to educate people what they are prohibited to do. Family mottoes make an organic unification of cultivating personalities, bearing oneself, or contributing to the society and then focus on elevating the realm of life and realizing the value of one's life.

\section{The MOtTo OF PATRIOTIC ViRTUES CUltivates THE YOUTH TO LOVE THEIR COUNTRY}

Patriotism is the key point of contemporary youth moral cultivation and is the value goal that contemporary youth should pursue. Young people should regard the love for a country as a kind of values that they should abide by unconsciously, connect their own futures and fortune with that of the country and the nation, aim high and go step by step. They should be brave to be the leader of the times and realize their dreams in the practice of making the Chinese dream come true. Only in this way can the Chinese dream of the great rejuvenation come true. Patriotism is the traditional virtue of the Chinese nation. There is no lack of passages about

*Fund Project: the humanities and social sciences research fund project for youth (16YJC710017) of the Ministry of Education. This article is supported by the basic business outlay of the central universities. educating children to love their country in traditional family mottoes, especially those of high officials. These lessons, first of all, are conducive to the cultivation of patriotic moral cognition in contemporary youth. Traditional family motto believes that family and country are interdependent and share a common destiny. Only when the big river is full can its branches be full. The happiness of the family is closely linked with the rise and fall of the country, and the prosperity of the country is the prerequisite for the prosperity of the family. On the other hand, the state is based on the family, and the harmony of thousands of families constitutes the harmony and stability of the country. To be patriotic, the young people in the first place are asked to set up the strong consciousness to love their country as loving their family. Love your country as much as you love your family and protect and defend the interests of your country as well as your own. Secondly, it is helpful to cultivate the moral feelings of the modern youth. "High officials should have more the concern for their country than only the words", "When you do not work for the government, you should respect your monarch; if you work for the country, you should work hard for the benefits of your people. You should be honest and leave your faithfulness to the world but not try to be dishonest to try to achieve status and money". In the traditional family mottoes, an aspiring young people should always concern about the world. With the moral value "When you do not work for the government, you should respect your monarch; if you work for the country, you should work hard for the benefits of your people", they should always take people's hardships inside the heart and concern about the rise and fall of the country. Loving the country is not a slogan that spoken by us, but our practical action. Wherever the young people are, whatever they are, they should concern about the country even they are ordinary people and regard the problems of the country as their own. As an ordinary people, they should regard to their monarch and get ready to sacrifice to their country; as officials they should think about the ordinary people and work for their benefits. Finally, it is helpful to cultivate the responsibility of the modern youth to serve the country. "Everyone is responsible for the rise and fall of his country", "National life is always permanent (longer than the individual), and we are always responsible for what we do. We do not have to worry about the results." It is widely believed in traditional family mottoes that it is the moral 
responsibility of all people to serve the country. For the rise and fall of the country, individuals can give all their own or even life. "Give my life to the country when it needs it is just like I go back home." "If my country needs me to sacrifice my life, I will not evade this because of my own benefits." These are all vivid portrays of sacrificing lives to countries. It was in this spirit that Yue Fei's mother stabbed him on the back with "repay the country with supreme loyalty", his father warned him that "it is a honor to die for the country because you are needed by the country." In Ming dynasty, Renming wrote a letter to his son on the war sight against invaders: "I take leading of the army but cannot beat the enemies, as a result thousands of people lost their homes. It is our time to live a hard life on the battlefields but we cannot repent and complain about the world like the prisoners of Chu." We are not sure about the stuff later. If we are lucky to win the war, then we can enjoy the happiness of the kinship of our family; if we are not lucky to win the war, I will die for the country, my wife will die for the honesty and my son die for the piety. We all work for the country. It shows the firm determination and the heroic spirit of the brave to kill the enemy and serve the country. The spirit reflected by these mottoes is for the country, for the people, and not afraid of sacrifice, which is very good to the contemporary youth education.

\section{The Motto of Aiming High CAn Cultivate Young PEOPLE'S AMBITION}

To aspire, in the moral field, is to cultivate a person to pursue the moral state of self-confidence and to become a sage. "You have to set up your goals to make your achievements high and you have only to be hardworking to make your career spread." Ambition is a beacon that guides youth forward. Lacking clear ambition makes one go far and far away from the goal of becoming a sage in the journey of life, even misguided. How to help the youth to set up the right aspiration relates to young people's healthy growth. Traditional family training attaches great importance to the cultivation of children and grandchildren and will aspire to be the most important thing in life. The first purpose of the discipline is to teach young people why they have to aspire. Traditional family mottoes believe that "life is like the road, one step wrong, it is not easy to turn back. One has first had a firm goal then can he have a firm determination." The family mottoes emphasized that set up aspiration is the most important thing in one's life, "One can achieve nothing without a goal; one is like a ship without the helm, or the horse without the nose stripe, disposed and drifted."The second is to teach young people what kind of aspiration should be set up. They should aim high. Traditional family mottos believe that lofty aspirations can inspire people's potential, strengthen their characters, and promote selfimprovement and progress. Family mottoes admonish your children that "you have to aim high and respect the sages in ancient times, refuse your lust and abandon the elements that will prevent you from progressing. To make the good qualities of the sages in ancient times clearly seen on us." Set up the goal to make progress. Traditional family precepts are generally accepted that the movement of the heaven (naturally) is strong, accordingly, gentleman's behavior should also be like the heaven, striving for progress, resolute and steadfast, hardworking but not lazy. Yuan Liaofan warned the descendants that we should strive to make progress but not be stubborn. "In the broad view, we should think about carrying forward the virtues of the forbears, in the narrow view, we should think about the goodwill of our parents; we should know the grace of our country and the kindness of our family; to the outside we should give our hand when someone is in urgent need think about the bad thoughts inside. We must think about what is bad and try to correct." Zuo Zongtang warned his son to learn from examples of the ancient sages, and he was out to be determined to learn and work hard. Aim for the goodness. The traditional family motto warns the following generations that they should follow the example of the ancient sages, have a broad mind, have the spirit of self-sacrifice, do not fear the difficulties of the moment, and do not care about the personal gain and loss. The third is to teach young people how to aspire. There are many useful insights in family mottoes. Zhuge Liang advocated that "the action of the gentleman should be kept calm in order to cultivate morality and be thrifty to cultivate virtue. Only not to seek fame and wealth can he make clear his goal and to be peaceful inside to be able to reach the goal."It is believed that ambition must be combined with the cultivation of morality and characters. Zuo Zongtang said that the worst thing is not to set up the goal, especially you are not determined. He believes that the ambition of the future is precious if it is constant. Once the ambition is established, one should be persistent but never half-hearted. These admonitions are of great guiding value for the determination and practice of young people.

\section{THE MOTTO OF HARD WORK HAS FOSTERED THE VIRTUE OF LEARNING}

The traditional family precepts pay great attention on the training of studious habit of the descendants and have very rich inspirational moral lessons, which provide important resources of academic reference and experience for reference. First of all, it helps to set up the correct learning orientation. The traditional family mottoes think that reading "is to cultivate the virtues and careers and the fame and the status are only accessories. It emphasizes that the purpose of reading is not to get a high official position or make their families honored, but by reading, to correct oneself, perfect oneself, to become a gentleman with a noble moral character and a good understanding of the etiquette, becoming the good man in the village, a good child of his parents. Secondly, it is conducive to correct learning attitude. The basic attitude of traditional family motto is: we have to be respectful in the first place. If we are respectful when we are reading, "we can understand even we are foolish. Though we may not be able to serve the government, we can show our piety to our parents. Though we cannot have achievements for the people of our country, we can make ourselves a good man." If we are not respectful to our study, we cannot be successful even we have tried for a life time. Even when we are successful we will be defeated one day. If we are officials we will do harm to our country; if we are ordinary people we will have no idea to protect ourselves. We have to be hardworking. "Since ancient times, the wise kings and the sages have to be very hardworking, let alone ordinary people like us." To be hardworking is the necessary attitude one should have while studying. From the aspect of time, we should study for the life time. "One piles of book is 
beneficial for this pile, one day's study is beneficial for this day." Don't give up learning at any time and at any age, and you should devote yourself to learning in a way that you can't wait to learning. Second, it is helpful to optimize the learning method. The traditional family motto emphasizes that you have to have a broad selection of the books you are reading. A person with a wide range of knowledge should read extensively and improve himself constantly. In addition to the four books and five classics, books about the county, food, customs, and others should be widely read. Don't read with utilitarian ideas, read extensively and increase your knowledge. Second, we have to read for a long time. While reading, we have to reciting the books about the six techniques with our hands turning pages of famous writers. It is necessary to persist, persevere and work for a long time to avoid "three days of fishing and two days of drying". Third, read thoroughly. Reading cannot be read without digesting; we cannot be satisfied with a little knowledge, but to master the essence of the book thoroughly and to read and understand the book. Finally, it is helpful to clarify the learning orientation. In the orientation of learning, the traditional family motto emphasizes that "the scholar has to learn but the action is the fundamental part" "Knowledge on books is ultimately shallow and we have to be practical to thoroughly understand it."It is believed that the fundamental point of reading is to practice, and to advocate "unity of knowledge and practice, so as to use the knowledge to guide us to practice". The key to reading, Zhu said, is to "work hard", to put the book into practice, and to learn how to behave. Sun Qifeng regard these who knows but does not behave as "illiteracy", stressing that reading must be used for the purpose of practice and knowledge should be combined with practice, and it is important to be used to ourselves and be used in practice. Lu Longhe said, reading and trying to be a good person is not two separate things. Put everything one has read into his practice is the method of reading and can be called reading. If you do not follow the truth in your book and separate reading from being a good person, you are not regarded as being able to read books.

\section{THE MOtTO OF BEING HONEST FOSTERs INTEGRITY}

"One cannot be without honesty." honesty is the basis and premise of interpersonal communication. If a person loses credibility, he will lose the trust of others and put himself in an awkward position. Honesty is a kind of moral quality to young people, and it is a kind of social responsibility, which is the foundation of youth. Promoting honesty in the youth is not only the basic requirements of cultivating and practicing the socialist core values. What's more, with its unique value of enlightenment and guidance, it promotes people to grow and thrive. Traditional family motto attaches great importance to the integrity of children and grandchildren. In the process of cultivating the integrity and morality of young people, these lessons can help to cultivate integrity. Traditional family motto believes that there are two ways to develop good faith character: "self-honesty" and "self-education of the honesty". "Self-honesty" is the internal conditions to develop honesty, referring to the nature of the person itself being not cheating and true to oneself. It stresses that within the scope of the heart of oneself, we should "not deceives oneself, don't cheat others, don't breach the doctrine of the heaven". "Self-education of the honesty" is the external conditions for the cultivation of good faith, the traditional family mottoes think people of integrity and moral character is not born but need to get through the external education. Only by receiving the good faith education can one achieve scientific cognitive system of integrity. Secondly, it helps to guide the practice of good faith. Traditional family motto believes that honesty is not an empty word, it needs to be practiced. In daily life, young people should focus three aspects to strengthen the cultivation of integrity: treating people, doing things, and focusing on. First, we should be honest with people. "Whenever we are dealing with people, we cannot get others moved without true feelings." "When we give others our promise, we have to try to realize it even it is very small; when we have an appointment with others, we should not change the time with even one second." "The most important thing about living in the world is to be honest. Once you have lost your credibility, you are queried in every situation." Traditional family motto believes that honesty is the golden rule of interpersonal communication, and a person can make real friends only if he is sincere to others. In the process of interpersonal communication, we should be responsible for our words and think carefully before we make our promises. We have to think clearly whether we can really do it when we make our promises. Once the commitment is made, we have to make our words countable keep your vows. Second, we should be honest with our workings. Traditional family mottoes believe that it is necessary to adhere to the principle of seeking truth from facts in any profession, avoiding being opportunistic or falsification. If you are an official, you should be careful and do not try to fraud. If you are a merchant, you should make your measurements equal and concord with the market, not too cheap or too expensive. Thirdly, we should be honest with our study. Traditional motto advocates that honesty is precious in study, emphasizing that we cannot be opportunistic in study, or pretend to understand when we do not really understand, or be mendacious. Zhang Ying warned his descendants that "we should not have an insatiable desire for the amount or the fame"; when we read one chapter, we must be able to recite it and try to understand its meaning and make full use of it. He Lun emphasized that we have read books for at least a hundred times. Only do we read and think about it for multiple times can we understand the meaning of it. Say the words of the books in our own words and understand its meaning form the deep of our heart. We have to achieve mastery through a comprehensive study of the subject. If we are not so mastery about the books, we just need to read hundred more times. And we still need to review from time to time. Zuo Zongtang proposed that we should use our eyes, mouth and heart while reading. We need to understand the usage of each word, the meaning of each sentence, and the reason of each incident. For the function word, we need to know the emotions hidden behind; for the content words, we need to know the exact meaning of them. We must know the words inside, being able to speak. Only in this way can we let it go.

\section{CONCLUSION}

Traditional family motto is an integral part of traditional Chinese culture. It reflects the essence of education thought in ancient family by its profound connotation and unique form. It 
pleases people's sentiment, edifies people's sentiment, motivates the people's mind, subtly influences the modern personality and ideal, psychological structure, fashion customs and spiritual quality. It is of great importance to help young people to establish high ideals, cultivate good characters and achieve perfect personalities to absorb the essence of moral education in traditional family mottoes in order to cultivate the virtues of loving the country, aiming high, being hardworking, being honest, being diligent, and being grateful.

\section{REFERENCES}

[1] Network center of the central commission for discipline inspection. Chinese regulations [M].Beijing: China founder press, 2017:223. 中央 纪委监察部网络中心.中国家规 [M]. 北京: 中国方正出版社, 2017:223.

[2] Lu Zhengyan. Chinese family training in ancient times [M] Shanghai: xuelin publishing house. 卢正言. 中国历代家训观止[M]上海: 学林出 版社. 2004.14

[3] (Ming dynasty) Yuan Liaoan. All four training [M] Zhengzhou: Zhongzhou Ancient Books Publishing House. （明）袁了凡.了凡四训 $[\mathrm{M}]$ 郑州: 中州古籍出版社.2010.47

[4] Lu Zhengyan. Chinese Family Mottoes [M]. Shanghai: Xuelin Press, 2004:217. 卢正言.中国历代家训观止 [M].上海: 学林出版社, 2004:217.

[5] (Qing dynasty) Kangxi. The Motto [M]. Zhengzhou: Zhongzhou Ancient Books press, 2010:152.（清）康熙.庭训格言[M].郑州: 中 州古籍出版社, 2010:152. 